Available online at: https://researchsynergy.org/ijmesh/

International Journal of Management, Entrepreneurship, Social Science and Humanities (IJMESH) ISSN 2580-0981 (online)

Volume 4 Number 2 (2021): 28-51

\title{
Missing out on the "Men's Club": Gendered Attitudes to Intrapreneurship within Large Corporations
}

\author{
Philip Meier' ${ }^{1}$ Simon Adderley ${ }^{2}$ \\ 1,2 Oxford Brookes University, United Kingdom
}

\begin{abstract}
This paper explores the factors that influence innovative and intrapreneurial behaviour amongst female employees. The paper explores a case study of one business unit (of approximately 1,100 employees) within a much larger corporation. It uses a qualitative methodology of semi-structured interviews to explore (1) the factors that influence innovative and intrapreneurial behaviour amongst female employees and (2) how these factors are influenced by the organisation. The paper is part of an emerging research agenda that explores gendered attitudes to intrapreneurial behaviour. This is an extremely under-researched area of research which tends to borrow heavily from studies into female self-employment. The paper demonstrates that rather than focus upon female attitudes to risk or lifestyle choices, the primary issue facing potential female intrapreneurs is implicit and explicit gatekeeping by male-dominated "innovation teams".
\end{abstract}

Keywords: Influence; Innovative; Intrapreneurial; Behaviour; Female; Employees.

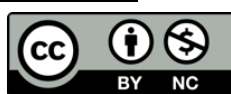

This is an open access article under the CC-BY-NC license.

\section{INTRODUCTION}

There is broad consensus that discontinuous innovations (Macher and Richman, 2004) or disruptive new technologies (Christensen, 1997) force organizations to adopt or change existing methods and processes (Sinha and Srivastava, 2013; Gawke et al., 2017; Casson 2008; Nelson and Winter, 1982). Corporations can only survive today's faster innovation cycles by becoming more innovative (Anthony et al., 2018) and adopting a more entrepreneurial culture and strategy (Bettis and Hitt, 1995; Zahra, 1991). Paradoxically, whilst executives consider innovation to be one of the top three areas for future economic growth, they tend not to rate their organisations' innovativeness very highly (Barsh et al., 2008). As a result, research into how to better exploit intrapreneurial activity leading to innovative outcomes is a significant area of academic interest (Casson, 2008).

However, the focus upon organisational capabilities has meant limited research has taken place exploring innovation at the individual level (Blanka, 2018; Gawke et al., 2019). As a result, there are crucial gaps in our understanding of the activities of actors within organizations (Casson, 2008; Wales, 2016). Existing research is limited in scope, lacks validation, and does not link to firm-level perspectives (Blanka, 2018; De Jong et al., 2015; Gawke et al., 2019). Moreover, research into organizational innovation tends to focus on single innovations, does not capture interrelatedness or account for different diffusion pathways (Rogers, 2003), and has created a gap between theorists and applied research (Casson, 2005). These failings are especially true with regards to gendered notions of intrapreneurship, with remarkably little research currently exploring the gender gap in internal entrepreneurship (see Adachi and Hisada, 2017 for a notable exception) 
This research aims to start filling these gaps through a case study approach that explores the implementation of a larger innovation project within a large European company. The research explores (1) the factors that influence innovative and intrapreneurial behaviour amongst female employees and (2) how these factors are influenced by the organisation. It follows the classical notion that the individual can only be properly understood in her/his social context and vice versa (Wright Mills, 1959).

The focus of this case study, Company $\mathrm{X}$, lags behind in innovative ideas and new product development. It is currently transitioning from analogue market research to the digital world in response to new competitors, new technologies, and new research methods (Brooke, 2018; Forsyth and Boucher, 2014). This research focuses mostly on one business unit in Company X with approximately 1,100 employees but also takes into account views from employees outside this one department to capture other views.

The paper outlines a conceptual framework consisting primarily of components from innovation, intrapreneurship, and entrepreneurship theories, specifically with regards to individual factors and the contextual factors influencing these individual factors.

\section{LITERATURE REVIEW}

Due to the long and changing history of research into innovation, researchers examining the factors that lead to innovative outcomes in organisations use a number of different labels and sub-fields to organise their work. The actions of individuals have been researched using a variety of labels: intrapreneur (Fry, 1987; Pinchot, 1985), entrepreneur (Schumpeter, 1934), innovator (Miller and Friesen, 1978), inventor (Schumpeter, 1934), creative constructionist (Pisano, 2019), and behavioural innovation (Wang and Ahmed, 2004).

Attempts have also been made to map individuals to specific types of organizations (Smith, 1967) or to combine certain aspects of one label with another. Miner et al. (1992) coined the inventorentrepreneur, though the jury is still undecided if one person can truly have the traits of both (Stibel, 2009). The value of investigating these labels is arguable that they serve as Weber-type ideal types (Adler, 2016) and thereby help in observing the real world or some aspects of it. Constructive typologies (McKinney, 1966) can have either fictional (but probable) properties or be purely grounded in empirically discoverable attributes, depending on the respective scholar's worldview. Consequently, we cannot expect to find the exact typologies described by the literature but rather an approximation of them.

This is especially true for gendered notions of intrapreneurship. Indeed, while the concept of gendered differences in entrepreneurial activity has received more (though not enough) attention recently, there is no significant body of work that explores gendered conceptions of intrapreneurship.

Regarding entrepreneurial behaviour, there is still a mixed bag of conclusions that can be drawn from the research. A number of studies have shown that being self-employed can be an attractive proposition to women who want greater autonomy over their work/life balance (Lombard 2001; Edwards and Field-Hendrey 2002). Macpherson (1988) and Carr (1996) argued that women with children favor self-employment owing to the flexibility with respect to time management that it offers.

Noseleit (2014) found that in a number of European countries, having children increases the likelihood of a woman being self-employed, while Patrick et al. (2016) found similar results in the 
United States. However, Saridakis et al. (2014) argued that in the UK, at least household variables are less significant than economic environments for both men and women in explaining self-employment choices

In reality, the topic is one that is likely to prove much more complicated than our current conclusions allow for. Fossen (2012) has shown that the majority of female aversion to self-employment comes not from risk aversion or lifestyle choices but from various subtle and embedded forms of discrimination toward women entrepreneurs. Calas et al. (2009) has expertly shown that the very definition of "entrepreneur" is couched in male terms, and thus there is a need to reframe entrepreneurship as social change without reliance upon economic metrics.

This emerging discourse has not spread to an examination of intrapreneurial activity. What work has been done seems to imply that women are more likely to express their inventiveness within organisations rather than through start-ups. Kacperczyk (2015) concluded that this finding was due to the fact that women prefer venturing opportunities within established organisations because this approach is both less risky and more profitable in the long term: Hamilton reported that independent entrepreneurs have lower initial earnings and lower earnings growth compared to employed people (2000) and Wang et al. (2012) found that entrepreneurs end up with less total wealth than similar wealthy households who do not engage in entrepreneurial activity.

For some of the research, this lack of clarity into the differences between intrapreneurship and entrepreneurship has to be critically taken into account when using it as a background for research projects that only a small sub-stratum is being sampled. For instance, Iqbal et al.'s (2006) study about risk aversion in women executives looks specifically at executive-level employees but leaves out everyone else, which arguably in most organisations is the majority. It is thus unrepresentative of women as a whole in organisations. Other research is contradictory. Again, whilst the Iqbal study found no difference in risk-taking, other studies did. Though cultural differences might play a role, one recent study in Ghana found differences in risk propensity (Hillesland, 2019), while another study in Ghana during the same time frame did not (Ackah et al., 2019).

Adachi and Hisada (2017) challenged Kacperczyk's assumptions that gender differences in risk-taking behavior do not cause the observed gender gap in entrepreneurial activities and argued that women found it more difficult to become intrapreneurs than independent entrepreneurs due to the existence of entrenched barriers within established organizations which do not exist to the same degree for start-ups.

Douglas and Fitzsimmons (2013) and Martiarena (2013) find that intrapreneurs are more risk-averse than entrepreneurs, and a number of studies have shown evidence that, controlling for other demographic characteristics, women are on average more risk-averse than men. (Croson and Gneezy, 2009)

This study shows that questions of aversion to risk are, in fact, mute and that the primary barrier to female intrapreneurship, in this case, study at least, was the existence of embedded "innovation teams" which were dominated by men and which implicitly and explicitly excluded female actors.

\section{Background context on Company X}

The case study organisation, Company X, is a large established firm based in Germany and with around 10,000 employees. It has struggled for a number of years to keep up with digitization and is currently 
going through a phase of change and restructuring, having been confronted with a changing industry landscape. The scale of the change is in line with earlier predictions and conceptualisations (Nelson and Winter (1982), Schumpeter (1934), Anderson and Tushman (1990)) that technological discontinuity forces Company $\mathrm{X}$ to change its internal routines dramatically and require new resources.

Company X's current top management has been installed by its two shareholders, one of whom is a private equity investor. Top management consists entirely of managers hired from outside Company $\mathrm{X}$.

Most of Company X's innovations are routine; innovations are seldom radical (Norman and Verganti, 2013; Pisano, 2015), though the new management team is concentrating upon a new prescriptive artificial intelligence service. Business models have remained mostly unchanged. At the time this research was conducted, it was not evident if the strategies that Company X employs would lead to success.

\section{Methodology}

This research utilised a series of semi-structured in-depth interviews (with samples equal to 21 respondents), mostly over Skype with two interviews conducted in cafes near the office. The interviews, which lasted approximately 55 minutes, were conducted with staff based in Germany utilising a semi-structured interview guide to ensure flexibility and to explore every participant's situation individually. The interview guide is the result of (a) the academic literature review and (b) the key informant interviews. It contains open-ended and closed-ended questions. The interview guide covers opportunities, risk-seeking and sensitivity, personality traits, demographics (e.g., age, sex), and the work environment. Terminology was clarified at the start of every interview,

Questions in the semi-structured interview guide were selected to reflect factors that have been proposed as relevant to firm-level entrepreneurial behaviour and individual-level intrapreneurship:

Organisational factors: Themes regarding organisational factors explored autonomy and job variety, the availability of incentives, and the availability of opportunities in the case study organisation through networking.

Individual-level factors: To address individual-level factors, the guide explored sensitivity and perception of risk, sensitivity, and perception towards rewards, competitive energy, innovativeness, and if participants felt they were intrapreneurial.

Sex and age: Themes regarding sex and age explored the roles that these characteristics play in Company $\mathrm{X}$ as well as personal or observed experiences with a focus on opportunities to be intrapreneurial and innovative.

For all questions, items were constructed in a way to allow for the exploration of the individual context as well as the organisational context. For instance, when asked about how competitive participants felt they were, the interviews also asked them if they thought that Company X rewarded this competitive behaviour.

Participants were selected participants using a sampling matrix that captured the participant's place in the organisational hierarchy of the organisation and should correlate with the number of resources 
available to the participant. Since gender was suggested in the key informant interviews as a worthwhile area of research, researchers also sampled for male and female participants. Furthermore, to participate in the in-depth interviews, participants must have been employees at Company $\mathrm{X}$ for at least 6 months and must be full-time employees. Participants were excluded if they were under 18 years of age, were interns, or had worked at Company X for less than 6 months. Saturation occurred after 21 interviews.

This research involved in-depth interviews $(n=21)$ and surveys $(n=20)$. The survey response rate of $16 \%(20 / 125)$ is towards the lower end of that recommended for business research publishing (Mellahi and Harris, 2016). Consequently, these results should be seen as indicative and require further research to confirm or challenge the primary conclusions. Participants' characteristics appear in Table 1, where they are compared to the general population in Germany. 
International Journal of Management, Entrepreneurship, Social Science and Humanities (IJMESH), Vol. 4 (2), 28-51

Missing out on the "Men's Club": Gendered Attitudes to Intrapreneurship within Large Corporations

Philip Meier, Simon Adderley

Table 1. Sample and general population characteristics. ${ }^{1}$

\begin{tabular}{|c|c|c|}
\hline Characteristics & Interview participants & General population \\
\hline Sex ratio (men:women) & $3: 1$ & $0.97: 1$ \\
\hline \multicolumn{3}{|l|}{ Age group (in years) } \\
\hline $18-24$ & $0.00 \%$ & $8.13 \%$ \\
\hline $25-29$ & $5.26 \%$ & $6.07 \%$ \\
\hline $30-39$ & $36.84 \%$ & $11.84 \%$ \\
\hline $40-49$ & $42.11 \%$ & $16.64 \%$ \\
\hline $50-64$ & $15.79 \%$ & $20.35 \%$ \\
\hline $65+$ & $0.00 \%$ & $11.26 \%$ \\
\hline \multicolumn{3}{|c|}{ Years working for Company $X^{2}$} \\
\hline $1-3$ & $15.79 \%$ & - \\
\hline $4-6$ & $36.84 \%$ & - \\
\hline $7-9$ & $36.84 \%$ & - \\
\hline $10-13$ & $10.53 \%$ & - \\
\hline $14-17$ & $5.26 \%$ & - \\
\hline $18-20$ & $10.53 \%$ & - \\
\hline $21+$ & $0.00 \%$ & - \\
\hline \multicolumn{3}{|c|}{ Professional experience (in years) } \\
\hline $1-3$ & $0.00 \%$ & - \\
\hline $4-6$ & $5.26 \%$ & - \\
\hline $7-9$ & $0.00 \%$ & - \\
\hline $10-13$ & $31.58 \%$ & - \\
\hline $14-17$ & $15.79 \%$ & - \\
\hline $18-20$ & $36.84 \%$ & - \\
\hline $21+$ & $21.05 \%$ & - \\
\hline \multicolumn{3}{|l|}{ Seniority } \\
\hline Ground-level & $57.89 \%$ & - \\
\hline Mid-level & $26.32 \%$ & - \\
\hline Upper level & $21.05 \%$ & - \\
\hline
\end{tabular}

\footnotetext{
${ }^{1}$ Source for the population statistics is Germany's Statistisches Bundesamt (DSTATIS, 2019).

2 Data from a 2015 study of the Institut der Deutschen Wirtschaft (iwd) shows that German employees stay at the same company for 12.9 years. Managers and specialists stay for 11.9 years on average. Age affects this only slightly (IWD, 2015).
} 
All in-depth interview participants were asked to self-assess on individual dimensions of intrapreneurship to give context to their viewpoints. Interestingly, most participants did not rate their reward sensitivity highly, but everyone said they were proactive. As shown in Diagram 1, most participants did not rate themselves intrapreneurial, though most rated themselves innovative. A notable exception was one vice president:

"I am not innovative in the sense that I develop new business models, but I am very good at expanding on existing business models."

- Man, 45-years-old, vice president

Diagram 1. Participant characteristics, each colour represents a different participant

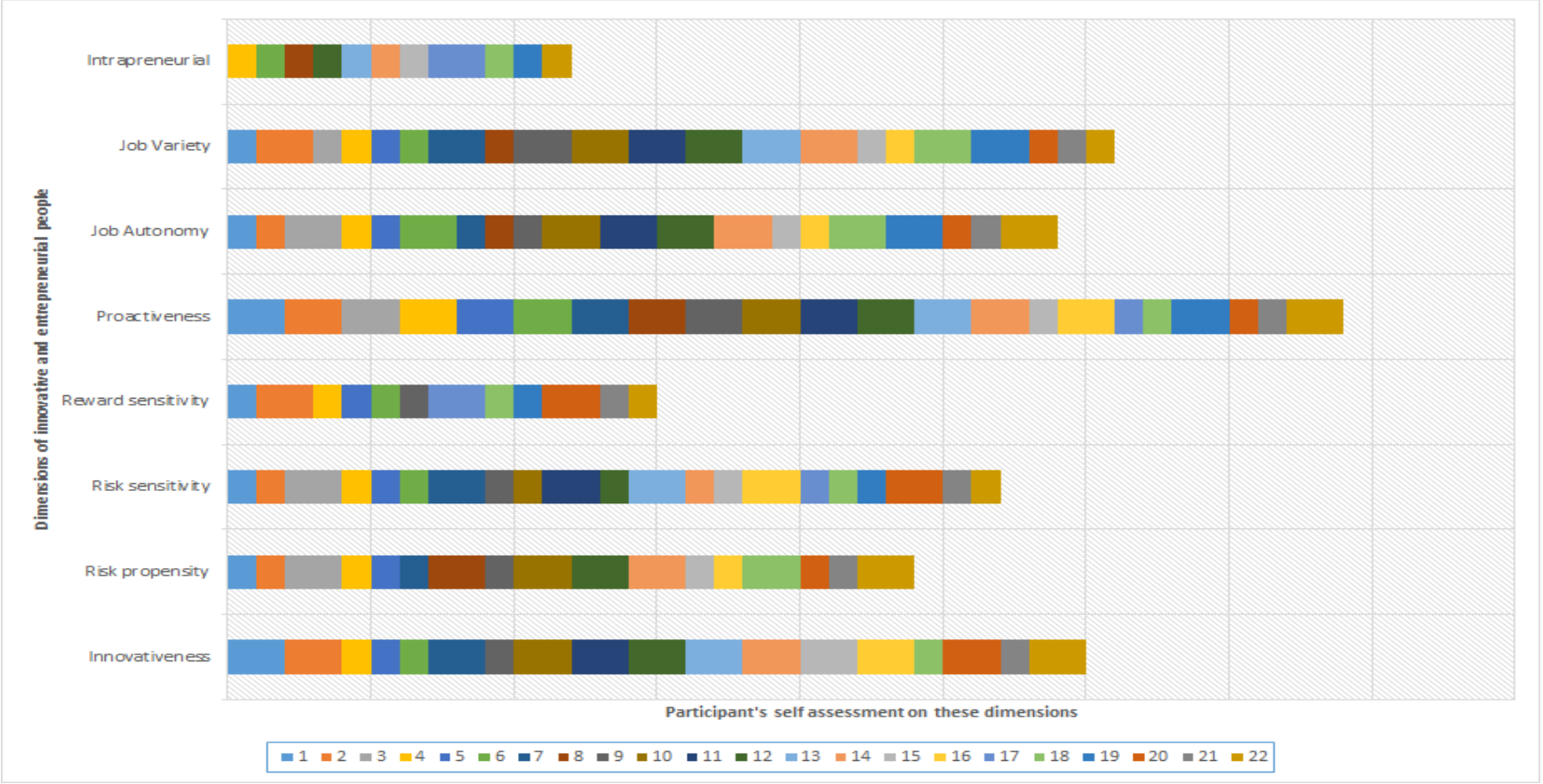


Each interview started by explaining the necessity of informed consent. Each participant was then asked to consent. The answer was recorded as part of the interview audio file. Every participant received a unique identification number that was used exclusively in all data analysis. No incentives were given apart from a free coffee during the one interview conducted over lunch.

Four interviews were conducted in English, and the rest were conducted in German. Amongst the interviews in English, one was done with a participant for whom his native languages are Spanish and Catalan; the others were done with participants for whom English is their native language. A direct translation approach was used (Saunders et al., 2015).

Filler words and false starts were largely omitted from the transcripts, but separate notes were taken to identify answers that seemed to cause the participants particular stress. Researchers also removed any names of companies and people to ensure anonymity. Parts of the interviews were lightly edited for conventions of English grammar and readability. The translation was done after the interviews were recorded but before analysis of the data.

Management at Company X approved the research. All participants gave consent, either oral (in which case it was recorded) or written before the interviews and surveys started. Participants were asked to exclude any personally identifiable data and to refrain from sharing business secrets regarding current and/or former employers and anonymise names of persons, projects, and entities.

A domain analysis approach was used for the generated data, as this research method is well suited for when repeat access to interviewees is possible for further research (Leech and Onwuegbuzie, 2007). The initial codebook's high-level themes were created a priori from the literature review and emerged in vivo from the key informant interviews in a combined approach (Dey, 1993). This process (Diagram 2) continued throughout the research process, as it increased the coder's reliability in finding themes (Carey et al., 1996). Since some participants gave interviews in their non-native language and some participants gave interviews in the interviewers' non-native language, no special attention was paid to the narrative structure apart from inconsistencies, repetitions, and silences (Poirier and Ayres, 1997).

From grounded theory, the constant comparison method (Glaser and Strauss, 1967) was used to discover similarities and differences in participants' replies and to inform data collection. I also identified metaphors and analogies (Lakoff and Johnson, 2003) and finally looked for exemplars (Lincoln and Guba, 1985). The data analysis workflow is shown in Diagram 2 below. 
International Journal of Management, Entrepreneurship, Social Science and Humanities (IJMESH), Vol. 4 (2), 28-51 Missing out on the "Men's Club": Gendered Attitudes to Intrapreneurship within Large Corporations

Diagram 2. Data analysis workflow

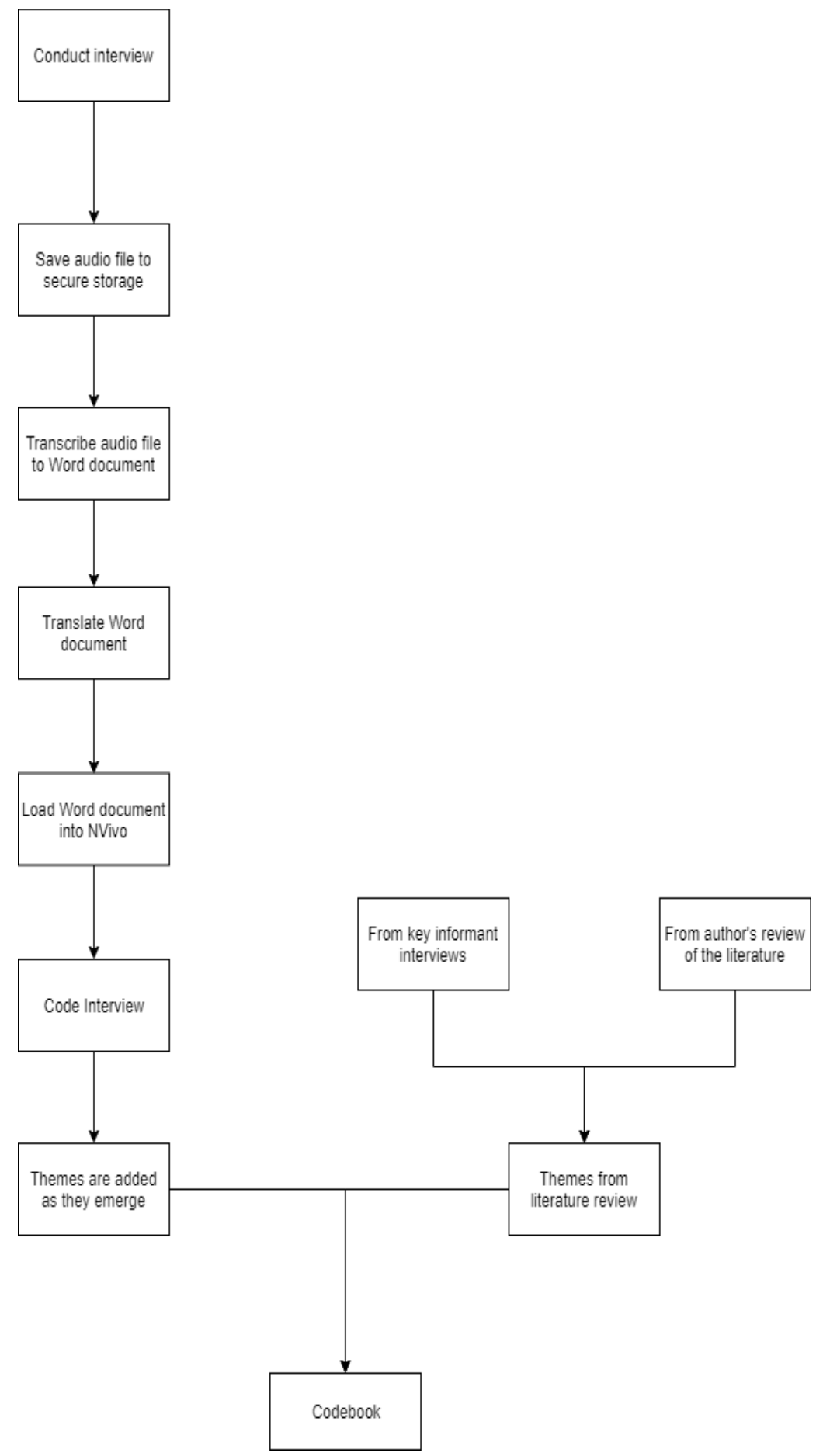


Codes aligned largely with what was expected from the literature review. Additionally, new codes were discovered revolving around the processes of what makes intrapreneurship and innovation possible in the organisation, as well as networking and differences between the sexes.

Secondary documents, both internal and external, were used to contextualize Company X and to better understand the motivations and actions of top management. These documents included regular emails and video interviews sent from the CEO to employees. Publically available news sources and industry publications were used to establish context and look for additional clues.

\section{RESULTS}

Three main themes emerged from the data, reported here in a top-down approach. Each section contains findings from the interviews, survey, and secondary data.

Theme 1: Unmanaged innovation is replaced by informal networks and processes that disadvantage outsiders and women

The research identified three different processes (Diagram 3) for innovators to obtain funding and make their ideas happen: one formal process, one semi-formal process, and one informal process. Only the semi-formal process was considered by primary research participants to produce promising results. It is, however, not available to everyone. Only a few employees from a single product group get special attention from the C-Level. A similar process exists in other departments but was considered by participants to be less successful in acquiring funding. The Innovation process at Company X is shown in Diagram 3 below. 


\section{Diagram 3. Innovation processes at Company X}

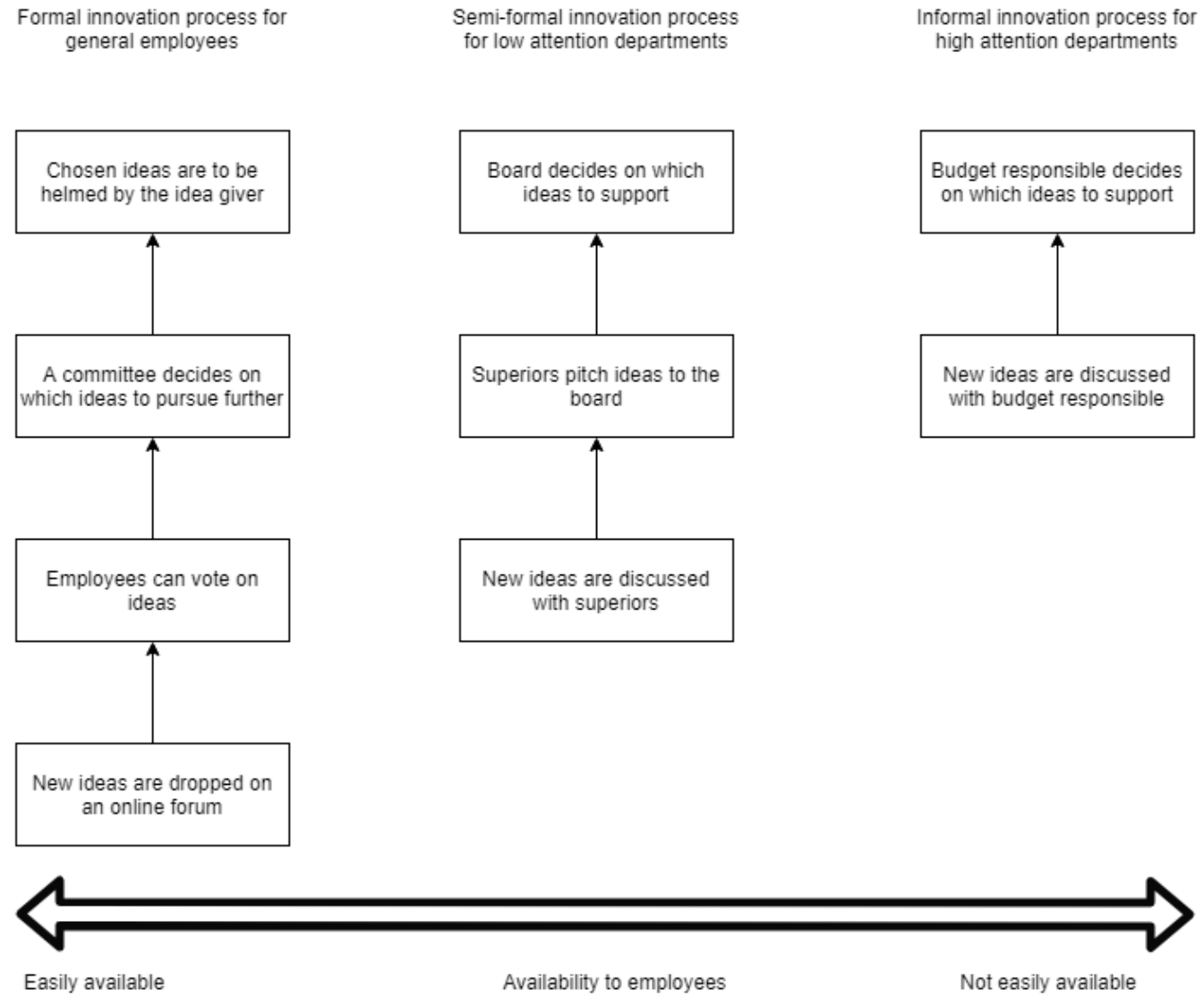

Participants talked about how some people or groups of people were capable of getting the attention and the funding needed to develop their ideas; however, they felt that access to these groups and processes was restricted. If special processes existed, they could be skipped by people who were better connected than others. Women more often reported limited access to the innovator's club (Diagram 4) than men; it is notable that participants reporting no limitations were exclusively men.

Diagram 4. Limited access to the innovator's club

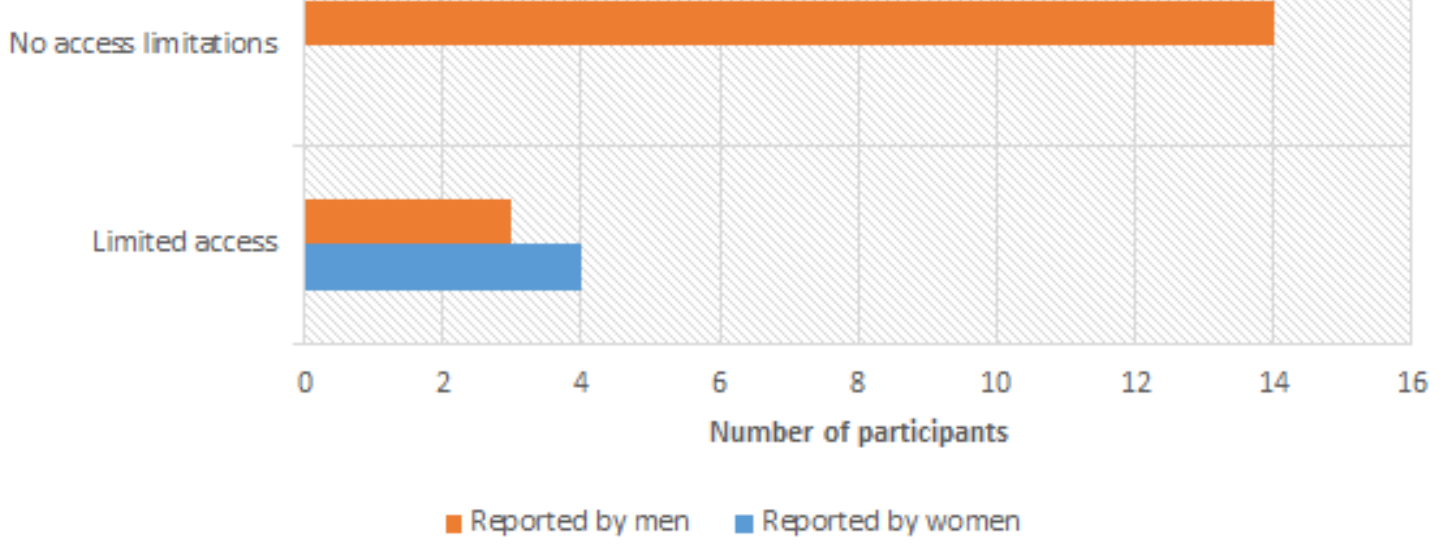


One woman explained it in detail:

\begin{abstract}
"It was, it was amazing how depending on who you were, you would, you would skip the innovation process. So I, for example, or people on my level would go through the entire process. So creating a business case, the POC pitching to the ward, pros, and cons. Like the typical innovation process, which I can't remember now 'cause I moved away from it. But people from the boards would have senior meetings with other companies when it had absolutely no relevance or did not go through that process. We would run pilots with companies that we never, we never did any of that innovation process. No one pitched it to the board, but because someone senior knew someone senior, that was completely skipped."
\end{abstract}

- Woman, 28-years-old, Innovation Manager

Theme 2: Access to opportunities had a greater correlation to gender than to seniority, with male employees benefitting from this

Though the internal communications from Company X's top management suggest that top management would like to create an inclusive culture where broad participation opportunities exist for all employees, the research results suggest that Company X is not quite there yet. Seniority level did not correlate with access to opportunities and the intrapreneurial process. Even the Vice President complained during his interview about closed-off groups of people who got all the funding and could skip processes. He also offered a different view on why women have it harder breaking into these circles:

"Men are generally, at least in my experience, in my professional career, most men in leadership positions are more assertive, as in, they are loud, they stand up for themselves, women have different tactics, but they are not heard."

- Man, 45 years, Vice President

To obtain privileged access to innovation processes, networking is key. Employees must break into these exclusive circles via networking, as noted by a participant who said she was good at making her voice heard:

"It's definitely my network. If you are not in a region and you're a manager or an associate director, I think you'd really, really struggle to get people to listen to your idea if you don't have a direct line."

- Woman, 28, Innovation Manager

Whilst networking is an important precursor to shortened innovation processes; this networking is not always perceived as being equally available to men and women. Socio-cultural norms and beliefs about the sexes can limit opportunities for networking opportunities outside of the office. One woman in senior management noted that, as a single woman, she had a difficult time networking with male colleagues outside the office since inviting a male colleague to a bar could be interpreted incorrectly as an advance. This participant thought that male colleagues likely felt similar constraints when considering networking with female colleagues outside the office. Consequently, single-sex networking opportunities protected both sexes from misunderstandings.

Another participant suggested that among men, these 'men's clubs' existed because men tend to work with other men with whom they get along well: 
"What I see frequently is that the people driving innovation, recruit their own team members, their best buddies with whom they worked on different projects, with whom they get along well or worked with at another employer. That happens frequently. I noticed that men tend to work with other men with whom they go out for a beer at night. It's like a men's club."

- Woman, 41 years, Sales Manager

While participant's from both sexes discussed their perceptions that networks exist in the organization with limited access to outsiders, only women suggested specific reasons why this access was limited for them:

"Football is one of those connecting elements. It is extreme. I have that discussion frequently with my husband, who, as it happens, was having dinner with his boys last night, and they only talked about football. That seems to be part of the men's world. There are more passionate topics men talk about, like football, that women don't care about. There is nothing similar between women, no similar topic. We don't go out and talk about food or tennis all night."

- Woman, 41 years, Sales Manager

Theme 3: The mental image of an intrapreneur shows a lack of diversified examples in Company X and tends to be male

Respondents were asked to come up with a mental image of an intrapreneur at Company X. All, but one said they imagined a European man in his 30s. This image was the same for both men and women. Participants were also asked about barriers, with a focus on intrapreneurial activity and opportunity exploitation. 11 respondents stated that they do not believe there were any barriers based on sex, 9 said they do think there are such barriers, including all women. The following answer from one participant is representative:

"Probably male. Um, probably white. Probably mid-thirties. I would say not someone new to the business, not necessarily someone who spent a long time on the business."

- $\quad$ Woman, 28 years, Innovation Manager

One female participant suggested that women have a harder time engaging in risky activities because they are more concerned about how they are perceived.

"And I mean, I can say as a girl, I definitely did not like making mistakes. So like this, you know, if you're in school or in a classroom and your teacher is asking a question, I did not like looking bad in front of people. And I think this is something that inhibits risk-taking. Of course, you have to be comfortable, the fact that you might fail. And I think somehow, not everyone, but there are more guys taking risks in general at a younger age and sort of saying, oh, it's okay if it didn't work out, so it's not a big deal."

- Woman, 38 years old, a ground-level employee with some managerial experience

While researchers did not have access to Company X's employees' demographics (e.g., ethnicity, age), their top management consists solely of white Europeans, and all but one are male. The only female executive runs the human resource department. 


\section{DISCUSSION}

This case study found that Company $\mathrm{X}$ is hindered by contradicting messages and insufficient rigour in implementing an organizational level strategy (Diagram 5) as well as resource and communications channel controlling informal networks in middle management. The effects these informal networks have on the diffusion of ideas are further amplified by gender adoption. The research suggests that three main reasons may lead the case study organization to act like it does:

Firstly, there is insufficient rigour in implementing an organizational level innovation strategy with the male-dominated 'innovator's club' being the manifestation of a principal-agent type-problem (Jensen and Meckling, 1976). Secondly, the implementation of a firm-level innovation strategy is not perceived as covering all departments of the case study organization, and as a result, the innovation is not widely supported. Finally, as a result of the former two issues, communication is uncoordinated and sometimes contradictory.

Diagram 5. A high-level overview of findings: innovation in Company X

\section{C-Level sends out two messages over different}

channels

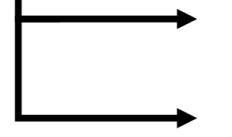

Be entrepreneurial, be innovative

Funding will only be granted if the likelihood

of a return is very high within the next twelve month

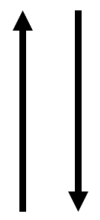

Informal network controls access to the limited

funding, doesn't pick up ideas from lower levels

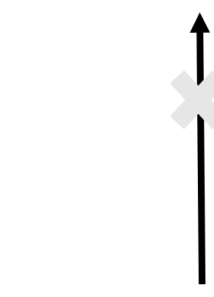

Ground-level generates ideas 
In the following sections, we link the research to sense-making theories and provide some concluding answers.

\section{Access to innovation processes}

The access people have to the processes to make innovations might be due to a number of reasons. Tacit knowledge (Polanyi, 1967) could be one reason. Some actors might simply know which strings to tap more than others. The lack of a defined innovation process would arguably help individuals with tacit knowledge to achieve their goals. Another explanation could be the development of an organisational routine (Cohen and Bacdayan, 1994) which limits how innovations, ventures, and new ideas are moved from individuals without the immediate power to act upon opportunities to those who do. Simply said, the guy who calls the shots might only talk to a select few. This would leave the question of why there are no procedures to collect and synthesize ideas from outside of this group. It generally questions the idea that the organization is a social community that enhances the transfer of new skills and capabilities (Zander and Kogut, 1995). Instead, it seems to suggest that groups within organizations can limit said transfer. The data does in no way hint at any motivating factors, but arguably there seems to be a principal-agent type problem (Jensen and Meckling, 1976) at play here, given that the organizational-level strategy seems, at least in principle, to welcome more innovation and entrepreneurial spirit in the case study organization. An alternative explanation leads back to Schumpeter (1934), who stated that innovations are new ways of combining resources or knowledge. The innovator's club at Company $\mathrm{X}$ might then just hint at a very innovative group of individuals who control access to resources to be innovative. Non-inclusive inter-organizational networks are not uncommon (Yamkovenko and Tavares, 2017), and research into how to uncover them has gained some traction in recent years due to an increased interest in diversity and inclusion (McKinsey, 2015).

The issues in obtaining funding from the C-Level, reported by the highest-ranking participants interviewed for this case study, as well as the apparent inconclusive communication, were already in 2006 described by Rosabeth Moss Kanter as classical innovation traps (2006).

\section{Focus on innovation}

There are implications beyond intrapreneurship. It challenges the classical view of organisations in which individuals are mostly self-motivated and act in their own best interest or that "organisations are social communities which use their relational structure and shared coding schemes to enhance the transfer and communication of new skills and capabilities" (Zander and Kogut, 1995, p. 1). Instead, the data suggest that individuals can form closed-off alliances, which might be informal or systemically created, which act as barriers to innovation and inter-organizational venturing, possibly to the benefit of its members.

This aspect is also currently not considered in EO research. Instead, EO assumes that top management represents corporate culture as a whole contributes to the entrepreneurial posture of the firm. It is also a factor that is not considered in the Miller/Covin Slevin scale.

Prior research has already demonstrated that board gender diversity leads to a decrease in potential reputation risks associated with aggressive tax strategies (Chen et al., 2019). Given that research has also shown that female managers are not more risk-averse than male managers, it is tempting to ask if the real difference is that men do not think of reputation and perception as components that have to be taken into account. This could have implications on cultural values and norms in that company execs would need to take gender differences into account when crafting visions, missions, and guidelines so that the right people draw the right conclusions. 
It seems thus reasonable to assume that to make the desired change happen in the organisation is highly path-dependent in that a number of prior actions are responsible for the outcomes of any actions towards the end goal of making the desired change, be it the implementation of a new innovation or the start of a new venture, happen. This is, of course, unfortunate for any organisation wishing to have a culture of fast reactions to changing market needs as it a) limits the number of people whose ideas are considered at all, and b) makes the organisation inflexible in that an organisation once created for a specific purpose with a specific goal, vision, and mission in mind is stuck with the members, skills, and choices once made.

What organisations do not configure their internal structure to capture the vast pool of ideas their internal (Kanter, 2006) and external network (HBS, 2019) could generate seems to be old news.

\section{Gender in the organizational context}

As discussed in the literature review, no notable gender differences have been found for a number of dimensions relevant to this research paper's research. Participants, however, reported on behavioural differences they had experienced, or they suggested these differences exist.

One of the upper management participants, who had significant professional experience, stated that he experienced women's tactics to be different then men's tactics (i.e., less assertive, quieter, do not stand up for themselves) prevent women from breaking into special networks, as women 'are not heard.' The women employees at Company X likely agree with his latter point, as women will never be heard at men's only networking opportunities after work due to a lack of access. However, the woman participants interviewed challenged his statement about women's tactics, with one woman reporting being good at making her voice heard. While gender differences in assertiveness are well documented in the research literature, there is no easy solution. Women who are more assertive are often seen unfavourably by colleagues, especially if these women are in leadership positions (Fielding-Singh et al., 2018; Wei Zheng et al., 2018). A possible solution to the problem of informal networking activities could be, for instance, for women to actively create these networking events by themselves, but in a context that better suits their needs, instead of going to a sports bar and watching football an after work dinner event might be better suited. However this is ultimately approached, the disconnect between the sexes suggests that unless senior management seeks to actively engage all employees, gendered barriers will limit access to opportunities for networking, resources, and privileged innovation processes.

\section{Issues of Definition}

A consistent theme of the research process was that interview participant did not always have a clear definition of innovation, entrepreneurship, or intrapreneurship. We found that they mix the latter two terms frequently. This was discovered in the key informant interviews and led researchers to add a definition of these terms, which could be read to the participants in case they lacked an understanding of the terms. Moreover, in a common-sense way, intrapreneurs are hard to identify: While someone who starts a business can with some certainty be called an entrepreneur, intrapreneurs often do not even realize what label they are given and ask peers did not lead to clear results either. Simply finding people who have already proven that they can launch new products or services leads into the same trap that has often been criticised about innovation research in general: It is ex post facto and thus only captures a portion of what is going on. At least in the case study organization, it was hard to find enough women for the samples. A reason might be the well-reported lack of women in technology 
(e.g., Conway et al.). However, the insights gained from the women in the sample were of particularly high value.

Lastly, as has been stated by others (Nelson and Winter, 1982; Polanyi, 1967), people who are intrapreneurial by nature tend to rely on a set of skills and knowledge, which is often tacit in nature. This, however, means they are not always fully aware of these skills and their knowledge, which poses a particular challenge to any research into the matter by means of qualitative or quantitative research.

A clear success was the realization that people are well aware of what innovation is and whatnot. They might not always be able to define it, but they know something to be an innovation if they see it. A non-academic-friendly innovation classification system could help as a tool for gaining more insights into innovation activity in organizations.

While Entrepreneurial Orientation metrics (E0) are useful for assessing an organisation's innovativeness and thus make statements about its business and marketing performance, there is a clear need for a research database that makes past measurement results available for benchmarking.

\section{CONCLUSION}

The original research questions this research paper set out to explore are: (1) the factors that influence innovative and intrapreneurial behaviour amongst female employees and (2) how these factors are influenced by the organisation.

To answer these questions, semi-structured interviews were conducted at the case study organization. Additionally, a survey was used to get answers from a larger population. Additionally, internal and external data sources were used to describe the employees' work context.

The findings seem to suggest that strategy makers at Company X send out two different messages, which lead to outcomes, not in line with senior management's primary message. We were unable to obtain data that would explain if this is intentional or unintentional. Company $\mathrm{X}$ bets on a single big new project while neglecting other areas of their business. We did not find any recommendations in the research or popular management literature prescribing this approach. More research is needed to determine how strategy makers use this approach, under which circumstances, and what its success criteria are.

The findings also provide insights into the processes, networking, and group formation at Company X:

- Company X pursues a single bet innovation strategy, putting large parts of the company into maintenance mode.

- Innovation is hindered by the strategy and internal groups that effectively control the innovation processes for their advantage.

- Gender plays a significant role in who gets to exercise innovation opportunities.

- Research participants' networks do not extend outside of Company X.

- Participants rate Company $\mathrm{X}$ below average on the dimensions of innovativeness, risk-taking, and proactivity. Given the strategy of Company X, it could be argued though, that these measurements are not representative of the company as a whole.

Company $\mathrm{X}$ is not at the end of its journey. Consequently, this research paper is limited in its ability to judge or measure success and failure. A follow-up study could try to extend this research after Company X has had time to finish the current adaptation cycle. Another weakness of this research is 
that it lacks direct data from important actors in the organization, especially from the C-Level. Thus, certain conclusions drawn in this research paper are more speculative than others. It has also been pointed out that observing a small group is not a valid way of measuring corporate innovativeness (Wang and Ahmed, 2004). As we have discussed, this research paper supports this view.

There is evidence that macroeconomic and industry factors can influence the outcomes mediated by EO's contributing factors in firms (Saeed et al., 2014). As stated earlier, this research paper does not take into account factors outside of the organisation and might thus be limited in its explanatory power.

\section{Implications and suggestions for future research}

As this case study captures only a relatively small timeframe, it would be interesting to research more organizations over much longer periods. This is especially in light of the often-stated weakness of prior studies, which are mostly ex post facto. Besides finding out how organizational implementations of innovation processes and strategies lead to outcomes, this author also thinks it would be worthwhile specifically reporting on unsuccessful businesses or approaches to innovation that is less mainstream. Also, studying closed-off social structures in organizations undergoing considerable change processes could be worthwhile. The relation of perception, reputation, and gender is an interesting component of future research, for instance, in a study that compares organizations in different cultural contexts. Finally, the author suggested that a strategy that splits an organization into areas of innovative progress and innovative stagnation requires considerations for the way EO research is conducted.

\section{REFERENCES}

Ackah, C.G., Aikins, E.R., Sarpong, T.T. and Asuman, D. (2019), “Gender differences in attitudes toward risk: Evidence from Entrepreneurs in Ghana and Uganda", Journal of Developmental Entrepreneurship: JDE, Vol. 24 No. 1, p. N.PAG-N.PAG.

Adachi, T. and Hisada, T. (2017) "Gender Differences in Entrepreneurship and Intrapreneurship: An Empirical Analysis,” Small Business Economics: An Entrepreneurship Journal, 48(3), pp. 447-486

Adler, P.S. (2016), The Oxford Handbook of Sociology, Social Theory, and Organization Studies: Contemporary Currents (Oxford Handbooks), Oxford University Press.

Anderson, P. and Tushman, M. (1990), "Technological Discontinuities and Dominant Designs: A cyclical model of dominant design", Administrative Science Quarterly, Vol. 35 No. 4, pp. 604633.

Anthony, S.D., Viguerie, P., Schwartz, I. and Van Landeghem, J. (2018), “Corporate Longevity Forecast: Creative Destruction is Accelerating", Innosight, available at: https://www.innosight.com/insight/creative-destruction/

Antshel, K.M. (2018), "Attention Deficit/Hyperactivity Disorder (ADHD) and Entrepreneurship", Academy of Management Perspectives, Academy of Management, Vol. 32 No. 2, pp. 243-265.

Arora, A., Belenzon, S., Patacconi, A. and Suh, J. (2019), "Why the U.S. Innovation Ecosystem Is Slowing Down", Harvard Business Review, 26 November,

Baker, S.E. and Edwards, R. (2012), "How many qualitative interviews is enough", NCRM, available at: http://eprints.ncrm.ac.uk/227

Baregheh, A., Rowley, J. and Sambrook, S. (2009), "Towards a Multidisciplinary Definition of Innovation", Management Decision, Vol. 47,

Barsh, J., Capozzi, M. and Davidson, J. (2008), "Leadership and innovation”, McKinsey Quarterly

Bazeley, P. and Jackson, K. (2013), Qualitative Data Analysis with NVivo, 2 Revised edition. SAGE Publications Ltd. 
Bernard, H.R. and Ryan, G. (2010), Analyzing Qualitative Data, 00001 ed., SAGE Publications, Inc, London,UK.

Bettis, R.A. and Hitt, M.A. (1995), "The New Competitive Landscape”, Strategic Management Journal, Vol. 16, pp. 7-19.

Bland, C.J., Meurer, L.N. and Maldonado, G. (1995), "A systematic approach to conducting a nonstatistical meta-analysis of research literature", Academic Medicine: Journal of the Association of American Medical Colleges, psycnet.apa.org, Vol. 70 No. 7, pp. 642-653.

Blanka, C. (2018), "An individual-level perspective on intrapreneurship: a review and ways forward", Review of Managerial Science, Springer

Bock, G.-W., Zmud, R.W. and Kim, Y.-G. (2005), "Behavioral intention formation in knowledge sharing: examining the roles of extrinsic motivators, social-psychological forces, and organizational climate", The Mississippi Quarterly, Vol. 29 No. 1, pp. 87-111.

Brooke, Z. (2018), “The Market Research Industry Is Being Squeezed by Consultancies”, American Marketing Association,

Calás, M.B., Smircich, L. and Bourne, K.A., 2009. Extending the boundaries: Reframing "entrepreneurship as social change" through feminist perspectives. Academy of Management Review, 34(3), pp.552-569.

Cantillon, R. (1755), “Essai sur la Nature du Commerce en General. In Higgs (ed.)”, London: Macmillan, 1931.

Carey, J.W., Morgan, M. and Oxtoby, M.J. (1996), "Intercoder Agreement in Analysis of Responses to Open-Ended Interview Questions: Examples from Tuberculosis Research”, CAMSI Journal. Journal ACEMI, SAGE Publications Inc, Vol. 8 No. 3, pp. 1-5.

Carr, D., 1996. Two paths to self-employment? Women's and men's self-employment in the United States, 1980. Work and occupations, 23(1), pp.26-53.

Casson, M. (2005), “The Individual - Opportunity Nexus: A Review of Scott Shane: A General Theory of Entrepreneurship", Small Business Economics, Vol. 24 No. 5, pp. 423-430.

Casson, M. (2008), The Oxford Handbook of Entrepreneurship (Oxford Handbooks in Business \& Management), edited by Yeung, B., Basu, A. and Wadeson, N., Oxford University Press, USA.

Chen, L.H., Gramlich, J. and Houser, K.A. (2019), "The effects of board gender diversity on a firm's risk strategies", Accounting \& Finance, Vol. 59 No. 2, pp. 991-1031.

Chesbrough, H. (2011), Open Services Innovation: Rethinking Your Business to Grow and Compete in a New Era, Jossey-Bass, SF, USA.

Chesbrough, H.W. (2006), Open Innovation: The New Imperative for Creating and Profiting from Technology, Harvard Business Press, Boston, MA, USA.

Christensen, C.M. (1997), The Innovator's Dilemma: When New Technologies Cause Great Firms to Fail (Management of Innovation and Change), Harvard Business Review Press.

Christensen, C.M., Gregersen, H.B. and Dyer, J.H. (2019), "The Innovator's DNA", Harvard Business Review

Ciuchta, M.P., Letwin, C., Huvaj, M.N., Stevenson, R. and McMahon, S. (2018), "Betting on the Coachable Entrepreneur: Signaling and Social Exchange in Entrepreneurial Pitches”, Entrepreneurship: Theory \& Practice, Vol. 42 No. 6, pp. 860-885.

Cohen, M.D. and Bacdayan, P. (1994), "Organizational Routines Are Stored as Procedural Memory: Evidence from a Laboratory Study", Organization Science, INFORMS: Institute for Operations Research, Vol. 5 No. 4, pp. 554-568.

Conte, J. (2018), "Sex versus Gender - Sociology - Oxford Bibliographies"

Covin, J.G. and Slevin, D.P. (1991), "A Conceptual Model of Entrepreneurship as Firm Behavior", Entrepreneurship Theory and Practice, SAGE Publications, Vol. 16 No. 1, pp. 7-26. 
Creswell, J.W. (2011), “Controversies in mixed methods research", The Sage Handbook of Qualitative Research, books.google.com, Vol. 4, pp. 269-284.

Croson, R. and Gneezy, U., 2009. Gender differences in preferences. Journal of Economic literature, 47(2), pp.448-74.

Dean, H., Larsen, G., Ford, J. and Akram, M. (2019), "Female Entrepreneurship and the Metanarrative of Economic Growth: A Critical Review of Underlying Assumptions", International Journal of Management Reviews, Vol. 21 No. 1, pp. 24-49.

De Jong, J.P.J., Parker, S.K., Wennekers, S. and Wu, C.-H. (2015), "Entrepreneurial behavior in organizations: does job design matter?", Entrepreneurship Theory and Practice, Wiley Online Library, Vol. 39 No. 4, pp. 981-995.

Dey, I. (1993), Qualitative Data Analysis: A User Friendly Guide for Social Scientists, Routledge.

Dodgson, M., Gann, D.M. and Phillips, N. (2015), The Oxford Handbook of Innovation Management (Oxford Handbooks), Reprint edition. Oxford University Press.

Douglas, E.J. and Fitzsimmons, J.R., 2013. Intrapreneurial intentions versus entrepreneurial intentions: distinct constructs with different antecedents. Small business economics, 41(1), pp.115-132.

Drucker, P. (1985), Innovation and Entrepreneurship, HarperCollins.

DSTATIS. (2019), "Homepage", Federal Statistical Office, available at: https://www.destatis.de/EN/Home/_node.html

Edwards, L.N. and Field-Hendrey, E., 2002. Home-based work and women's labor force decisions. Journal of labor Economics, 20(1), pp.170-200

Eisenmann, T.R. (2013), "Entrepreneurship: A working definition”, Harvard Business Review, academia.edu, Vol. 10,

ESOMAR. (2019), “ESOMAR Global Market Research Report 2019”, ESOMAR

Evans, D.S. and Jovanovic, B. (1989), "An Estimated Model of Entrepreneurial Choice under Liquidity Constraints", The Journal of Political Economy, journals.uchicago.edu, Vol. 97 No. 4, pp. 808827.

Evans, D.S. and Leighton, L.S. (1987), Self-Employment Selection and Earnings over the Life Cycle, US Small Business Administration, Office of Advocacy.

Fielding-Singh, P., Magliozzi, D. and Ballakrishnen, S. (2018), "Why Women Stay Out of the Spotlight at Work", Harvard Business Review Digital Articles, Harvard Business School Publication Corp., pp. 2-6.

Forsyth, J. and Boucher, L. (2014), "Winning the research revolution”, McKinsey

Fossen, F.M., 2012. Gender differences in entrepreneurial choice and risk aversion-a decomposition based on a microeconometric model. Applied Economics, 44(14), pp.1795-1812.

Fry, A. (1987), "The post-it note: An intrapreneurial success", SAM Advanced Management Journal, Society for the Advancement of Management, Vol. 52 No. 3, p. 4.

Gatignon, H., Tushman, M.L., Smith, W. and Anderson, P. (2002), "A Structural Approach to Assessing Innovation: Construct Development of Innovation Locus, Type, and Characteristics", Management Science, INFORMS, Vol. 48 No. 9, pp. 1103-1122.

Gawke, J.C., Gorgievski, M.J. and Bakker, A.B. (2019), "Measuring intrapreneurship at the individual level: Development and validation of the Employee Intrapreneurship Scale (EIS)", European Management Journal

Gile, K.J. and Handcock, M.S. (2010), "Respondent-Driven Sampling: An Assessment of Current Methodology", Sociological Methodology, journals.sagepub.com, Vol. 40 No. 1, pp. 285-327.

Glaser, B.G. and Strauss, A.L. (1967), The Discovery of Grounded Theory: Strategies for Qualitative Research, Aldine. 
Groves, R.M., Fowler, F.J., Couper, M.P., Lepkowski, J.M., Singer, E. and Tourangeau, R. (2009), Survey Methodology (Wiley Series in Survey Methodology), 2. edition. Wiley.

Hamilton, B.H. (2000), "Does entrepreneurship pay? An empirical analysis of the returns to selfemployment", The Journal of Political Economy, The University of Chicago Press, Vol. 108 No. 3, pp. 604-631.

Hamilton, W.D. (1964), "The genetical evolution of social behaviour. I", Journal of Theoretical Biology, Vol. 7 No. 1, pp. 1-16.

Hartley, J. (2014), "Some thoughts on Likert-type scales", International Journal of Clinical and Health Psychology: IJCHP, Elsevier, Vol. 14 No. 1, pp. 83-86.

HBS. (2019), “How Big Companies Can Outrun Disruption”, HBS Working Knowledge,

Herrington, M. (2017), Global Entrepreneurship Monitor Policy Briefs 2017.

Hillesland, M. (2019), "Gender differences in risk behavior: An analysis of asset allocation decisions in Ghana”, World Development, Vol. 117, pp. 127-137.

Hirsch, P., Koch, I. and Karbach, J. (2019), "Putting a stereotype to the test: The case of gender differences in multitasking costs in task-switching and dual-task situations", PloS One, Vol. 14 No. 8

Hofer, C.W. (1973), "Some Preliminary Research on Patterns of Strategic Behaviour", Academy of Management, pp. 46-54.

Howell, J.M. and Higgins, C.A. (1990), "Champions of Technological Innovation", Administrative Science Quarterly, Administrative Science Quarterly, Vol. 35 No. 2, pp. 317-341.

Iqbal, Z., O, S. and Baek, H.Y. (2006), “Are Female Executives More Risk-Averse than Male Executives?”, Atlantic Economic Journal: AEJ, Springer Nature, Vol. 34 No. 1, pp. 63-74.

IWD. (2015), "M+E-Industrie: Mitarbeiter bleiben lange in ihren Betrieben", Iwd,

Jensen, M.C. and Meckling, W.H. (1976), "Theory of the Firm: Managerial Behavior, Agency Costs and Ownership Structure", Journal of Financial Economics, Vol. 3 No. 4, pp. 305-360.

Johnson, S.L., Madole, J.W. and Freeman, M.A. (2018), “Mania Risk and Entrepreneurship: Overlapping Personality Traits", Academy of Management Perspectives, Academy of Management, Vol. 32 No. 2, pp. 207-227.

Johnson, W.R. (1978), "A Theory of Job Shopping”, The Quarterly Journal of Economics, Oxford University Press, Vol. 92 No. 2, pp. 261-278.

Kacperczyk, A. (2015), "Female entrepreneurship and alternative opportunities inside an established firm", Unpublished Manuscript

Kanter, R.M. (2006), "Innovation: The Classic Traps”, Harvard Business Review, 1 November

Kirzner, I.M. (1973), "Competition and Entrepreneurship"

Koellinger, P. (2008), "Why are some entrepreneurs more innovative than others?", Small Business Economics, Vol. 31 No. 1, p. 21.

Kotter, J.P. (2012), Leading Change, Harvard Business Review Press, Boston, MA, USA.

Lakoff, G. and Johnson, M. (2003), Metaphors We Live By, Revised ed., University of Chicago Press.

Leech, N.L. and Onwuegbuzie, A.J. (2007), "An array of qualitative data analysis tools: A call for data analysis triangulation", School Psychology Quarterly: The Official Journal of the Division of School Psychology, American Psychological Association, Vol. 22 No. 4, pp. 557-584.

Lincoln, Y.S. and Guba, E.G. (1985), Naturalistic Inquiry, SAGE.

Lombard, K.V., 2001. Female self-employment and demand for flexible, nonstandard work schedules. Economic inquiry, 39(2), pp.214-237.

Loten, A. (2019), “Older IT Workers Left out despite Tech Talent Shortage”, WSJ Online, wsj.com, 25 November, available at: https://www.wsj.com/articles/older-it-workers-left-out-despitetech-talent-shortage- 11574683200 
Lumpkin, G.T. and Dess, G.G. (1996), “Clarifying the Entrepreneurial Orientation Construct and Linking It To Performance”, AMRO, Academy of Management, Vol. 21 No. 1, pp. 135-172.

Macher, J.T. and Richman, B.D. (2004), “Organizational Responses to Discontinuous Innovation: A Case Study Approach", 1 March,

Macpherson, D.A., 1988. Self-employment and married women. Economics Letters, 28(3), pp.281-284

Markman, A. (2012), "How to Create an Innovation Ecosystem", Harvard Business Review, 4 December,

Martiarena, A., 2013. What's so entrepreneurial about intrapreneurs?. Small Business Economics, 40(1), pp.27-39.

Martin, R.L. (2009), Opposable Mind: Winning through Integrative Thinking, Harvard Business Review Press.

Masters, R. and Meier, R. (1988), "Sex differences and risk-taking propensity of entrepreneurs", Journal of Small Business Management, Wiley-Blackwell, Vol. 26 No. 1, pp. 31-35.

McKinney, J.C. (1966), Constructive Typology and Social Theory, Ardent Media.

McKinsey. (2015), "Why diversity matters", available at: https://www.mckinsey.com/businessfunctions/organization/our-insights/why-diversity-matters

Mellahi, K. and Harris, L.C. (2016), "Response Rates in Business and Management Research: An Overview of Current Practice and Suggestions for Future Direction", British Journal of Management, Wiley-Blackwell, Vol. 27 No. 2, pp. 426-437.

Menges, L. (2019), "Esomar Global Market Research Report 2019: Insights-Branche wächst leicht"

Miller, D. and Friesen, P.H. (1978), "Archetypes of Strategy Formulation", Management Science, INFORMS, Vol. 24 No. 9, pp. 921-933.

Miller, R.A. (1984), "Job Matching and Occupational Choice", The Journal of Political Economy, journals.uchicago.edu, Vol. 92 No. 6, pp. 1086-1120.

Miner, J.B., Smith, N.R. and Bracker, J.S. (1992), "Defining the Inventor-Entrepreneur in the Context of Established Typologies", Journal of Business Venturing, Vol. 7 No. 2, p. 103.

Morgan, J. (2015), “The Innovation Ecosystem for The Future Of Work”, Forbes Magazine, Forbes, 12 August

Nelson, R.R. and Winter, S.G. (1982), An Evolutionary Theory of Economic Change, Harvard University Press.

Norburn, D. (1986), "Beyond Intrapreneurship: The Metamorphosis of Larger Corporations", Leadership \& Organization Development Journal, MCB UP Ltd, Vol. 7 No. 3, pp. 21-26.

Norman, D. and Verganti, R. (2013), "Incremental and Radical Innovation”, Design Issues.

Noseleit, F., 2014. Female self-employment and children. Small Business Economics, 43(3), pp.549569.

Patrick, C., Stephens, H. and Weinstein, A., 2016. Where are all the self-employed women? Push and pull factors influencing female labor market decisions. Small Business Economics, 46(3), pp.365-390.

Pinchot, G. (1985), Intrapreneuring: Why You Don't Have to Leave the Corporation to Become an Entrepreneur, First Edition., Joanna Cotler Books.

Pisano, G.P. (2015), "You need an innovation strategy", Harvard Business Review, Harvard Business School Publication Corp., Vol. 93 No. 6, pp. 44-54.

Pisano, G.P. (2019), Creative Construction: The DNA of Sustained Innovation (English Edition), Kindle., Public Affairs.

Poirier, S. and Ayres, L. (1997), "Endings, secrets, and silences: overreading in narrative inquiry", Research in Nursing \& Health, Vol. 20 No. 6, pp. 551-557.

Polanyi, M. (1967), The Tacit Dimension. 
Rauch, A., Wiklund, J., Lumpkin, G.T. and Frese, M. (2009), "Entrepreneurial Orientation and Business Performance: An Assessment of Past Research and Suggestions for the Future", Entrepreneurship: Theory \& Practice, Vol. 33 No. 3, pp. 761-787.

Rogelberg, S.G. and Stanton, J.M. (2007), "Introduction Understanding and Dealing With Organizational Survey Nonresponse", Organizational Research Methods, Vol. 10 No. 2, pp. 195-209.

Rogers, E.M. (2003), Diffusion of Innovations, 5th Edition, 5th ed., Free Press.

Saeed, S., Yousafzai, S.Y. and Engelen, A. (2014), "On Cultural and Macroeconomic Contingencies of the Entrepreneurial Orientation-Performance Relationship", Entrepreneurship Theory and Practice, SAGE Publications Inc, Vol. 38 No. 2, pp. 255-290.

Saridakis, G., Marlow, S. and Storey, D.J., 2014. Do different factors explain male and female selfemployment rates?. Journal of Business Venturing, 29(3), pp.345-362.

Saunders, M., Lewis, P. and Thornhill, A. (2015), Research Methods for Business Students, 7th edition. Financial Times Prent.

Schon, A.D. (1963), “Champions for Radical New Inventions", Harvard Business Review, Vol. 41, pp. 77-86.

Schumpeter, J.A. (1934), Theory of Economic Development, New ed., Harvard University Press, Mass, USA.

Scott, S.G. and Bruce, R.A. (1994), "Determinants of innovative behavior: a path model of individual innovation in the workplace", Academy of Management Journal. Academy of Management, Academy of Management, Vol. 37 No. 3, pp. 580-607.

Smith, N.R. (1967), "The Entrepreneur and His Firm: The Relationship between Type of Man and Type of Company", Cambridge University Press

Steensma, H.K. and Corley, K.G. (2001), "Organizational Context as a Moderator of Theories on Firm Boundaries for Technology Sourcing", Academy of Management Journal, Academy of Management, Vol. 44 No. 2, pp. 271-291.

Stibel, J. (2009), "Are You an Inventor or an Entrepreneur?", Harvard Business Review, 30 June

Strobl, A., Niedermair, J., Matzler, K. and Mussner, T. (2019), "Triggering subordinate innovation behavior: the influence of leaders' dark personality traits and level 5 leadership behavior", International Journal of Innovation and Technology Management, Vol. 23 No. 5,

Teece, D.J., Pisano, G. and Shuen, A. (1997), "Dynamic capabilities and strategic management", Strategic Management Journal,

Urbancova, H. (2013), "Competitive advantage achievement through innovation and knowledge", Journal of Competitiveness, Tomas Bata University in Zlin, Faculty of Management and Economics, Vol. 5 No. 1

Wales, W.J. (2016), "Entrepreneurial orientation: A review and synthesis of promising research directions", International Small Business Journal: Researching Entrepreneurship, Vol. 34 No. 1, pp. 3-15.

Wales, W.J., Gupta, V.K. and Mousa, F.-T. (2013), "Empirical research on entrepreneurial orientation: An assessment and suggestions for future research", International Small Business Journal, SAGE Publications Ltd, Vol. 31 No. 4, pp. 357-383.

Wang, C.L. and Ahmed, P.K. (2004), "The development and validation of the organisational innovativeness construct using confirmatory factor analysis", European Journal of Innovation Management, Emerald Group Publishing Limited, Vol. 7 No. 4, pp. 303-313.

Wang, C., Wang, N. and Yang, J. (2012), "A unified model of entrepreneurship dynamics", Journal of Financial Economics, Vol. 106 No. 1, pp. 1-23. 
Wei Zheng, Kark, R. and Meister, A. (2018), "How Women Manage the Gendered Norms of Leadership”, Harvard Business Review Digital Articles, Harvard Business School Publication Corp., pp. 16.

Wells, L.E. and Sweeney, P.D. (1986), "A Test of Three Models of Bias in Self-Assessment", Social Psychology Quarterly, [Sage Publications, Inc., American Sociological Association], Vol. 49 No. 1, pp. 1-10.

Wiklund, J., Hatak, I., Patzelt, H. and Shepherd, D.A. (2018), “Mental Disorders in the Entrepreneurship Context: When Being Different Can Be An Advantage", Academy of Management Perspectives, Academy of Management, Vol. 32 No. 2, pp. 182-206.

Wright Mills, C. (1959), The Sociological Imagination, Anniversary. Oxford University Press, U.S.A.

Yamkovenko, B. and Tavares, S. (2017), "To Understand Whether Your Company Is Inclusive, Map How Your Employees Interact", Harvard Business Review Digital Articles, Harvard Business School Publication Corp., pp. 2-8.

Yin, R.K. (2018), Case Study Research and Applications: Design and Methods, 6th edition., Sage Publications Ltd.

Yin, R.K. and Davis, D. (2007), "Adding new dimensions to case study evaluations: The case of evaluating comprehensive reforms", New Directions for Evaluation, Wiley Online Library, Vol. 2007 No. 113, pp. 75-93.

Yuan, F. and Woodman, R.W. (2010), "Innovative Behavior in the Workplace: The Role of Performance and Image Outcome Expectations", Academy of Management Journal, Academy of Management, Vol. 53 No. 2, pp. 323-342.

Zahra, S.A. (1991), "Predictors and Financial Outcomes of Corporate Entrepreneurship: An Exploratory Study", Journal of Business Venturing, Vol. 6 No. 4, p. 259.

Zander, U. and Kogut, B. (1995), "Knowledge and the Speed of the Transfer and Imitation of Organizational Capabilities: An Empirical Test”, Organization Science, INFORMS, Vol. 6 No. 1, pp. 76-92.

Zwilling, M. (2012), "Inventor-Entrepreneur Pairs are Ideal for a Startup”, Forbes Magazine, Forbes, 2 May 